\title{
Effect of Massage on Sleep Quality and Motor Development in Infant Aged 3-6 Months
}

\author{
Nurry Ayuningtyas Kusumastuti'), Didik Tamtomo²), Harsono Salimo3) \\ 1)Masters Program in Public Health, Universitas Sebelas Maret \\ 2)Faculty of Medicine, Universitas Sebelas Maret \\ 3)Department of Pediatrics, Dr. Moewardi Hospital, Surakarta
}

\begin{abstract}
Background: In theory, infant massage is beneficial for improving sleep quality, gross and fine motor development. Infants aged 3-6 months are able to receive stimulation that may help develop gross and fine motor development. Massage may improve brain function and raise the release of growth hormone, and strengthen muscle. This study aimed to determine of the effect of massage on sleep quality, gross and fine motor development among infant aged 3-6 months.

Subjects and Method: This was a randomized controlled trial, conducted in Magelang, Central Java, from 1 August to 16 September 2016. A total of 60 infants in Azza Momby Spa, Magelang was selected for this study by simple random sampling. This sample was then allocated at random into massage group $\left(\mathrm{n}_{1}=30\right)$ and control group $\left(\mathrm{n}_{2}=30\right)$. The independent variable was infant massage. The dependent variables were sleep quality, gross and fine motor development. The data was collected by using questionnaire. The difference of dependent variables between the two groups were tested by Mann-Whitney.

Results: After intervention, infants in the massage group (median=2.00; $\mathrm{SD}=1.80$ ) slept better than the control group (median<0.01; $\mathrm{SD}=0.95)$, and it was statistically significant $(\mathrm{p}<0.001)$. Infants in the massage group (median $=0.00 ; \mathrm{SD}=0.81$ ) had better gross motor development than the control group (median<0.01; $\mathrm{SD}=0.72$ ), and it was statistically significant $(\mathrm{p}=0.043)$. Infants in the massage group (median $=0.00 ; \mathrm{SD}=0.81$ ) had better fine motor development than in the control group (median< $<0.01 ; \mathrm{SD}=0.48)$, and it was statistically significant $(\mathrm{p}=0.018)$.

Conclusion: Massage is effective to improve sleep quality, gross and fine motor development, in infants aged 3-6 months.
\end{abstract}

Keywords: massage, sleep quality, gross and fine motor development, infants

\section{Correspondence:}

Nurry Ayuningtyas Kusumastuti. Masters Program in Public Health, Sebelas Maret University, Surakarta. Email: nurry0067@yahoo.com.

\section{BACKGROUND}

Baby massage is useful for improving the sleeping quality (Ishikawa and Shiga, 2012), gross motor development, and fine motoric (Roesli, 2013). The government has given attention to the growth and development of infants through the role of midwives as stipulated in the Decree of the Minister of Health of the Republic of Indonesia Number 369/Ministry of Health/ SK/III/2007 concerning Midwife Professional Standards which states that midwives have the authority to carry out monitoring and stimulate growth of infants and children. During this time one form of stimulations that developed in stimulating baby's growth and development was by doing baby massage (Kepmenkes RI, 2007).

Infancy is a golden age because at this happens very quickly and could not be repeated. In addition, it is also called a critical period because the baby is very sensitive to the surrounding environment, requires adequate nutrition, and good stimulation to support the process of growth and development. At this time, the 
brain development of babies who have plasticity will continue (Ministry of Health, 2009; Zero to Three, 2012).

Babies are weak individuals and need some adaptation, so if the baby has a difficulty in the process of adaptation, it will affect its development, causing irregular behavior, even the most fatal consequences is death (Mansyur, 2009). The sensation of touch is very important in the beginning of a baby's life to adapt to his environment. Stimulation of touch on the baby influences positive psychosocial development (Polat, 2012).

At the age of 3 months and above, babies are able to receive stimuli and touch. In addition, at the age of 4-6 months the baby is at a time when the development of the motor will grow faster (Ministry of Health, 2010). Baby's muscle strength will increase as the baby ages. At this age, the development of brain cells is very rapid, so that with baby massage therapy routinely and continuously, it can strengthen the relationships between nerves that have been formed in order to improve brain function (Chamida, 2009; Roesli, 2008).

According to Vina (2010), when sleeping soundly, the baby's brain growth will reach its peak because the baby's body will produce three times more growth hormone than when the baby is awake. Therefore, babies who sleep longer, the baby's growth and development will be achieved optimally and it will allow the body to repair and renew all the cells in the body (Helen et al., 2005; Prasetyono, 2012; Schoefer et al., 2007; Widiyanti et al., 2008).

Parents are the easiest to see the development of their babies, namely in the development of body movements which include gross motoric and fine motoric (Ministry of Health, 2010). Baby massage provides a stimulus in motor development because squeeze movements on baby massage can be useful for strengthening baby's muscles (Roesli, 2013). According to Halimah et al., (2012), infant massage can have a positive motoric effect, including the ability to control the coordination of the fingers, arms, body, and legs.

The purpose of this study was to analyze the effect of an infant/baby massage on the sleeping quality, gross motor development, and fine motoric in infants aged 3-6 months.

\section{SUBJECTS AND METHOD \\ This was a randomize controlled trial conducted at Magelang Health Center and Azza Momby Spa, from August 1 to September 16, 2016. The study population of all 3-6 months infants in the Central Magelang Health Center was 145 healthy and not congenital defects. The subjects of the study used simple random sampling with 30 babies who received infant massage treatment. \\ Data on sleeping quality was measured by BISQ questionnaire. The other variables were measured by questionnaire. The data were analyzed by Mann Whitney test.}

\section{RESULTS}

\section{Study Subjects Characteristics}

The results of the characteristics of the study subjects in Table 1 show that there are 30 study subjects in the intervention group and 30 in control groups. The description of study variables is explained based on characteristics, criteria, frequency, and percentage.

Most infants were 3 months old in the intervention group of 14 infants (46.7\%) and the control group was 18 infants (60\%). All study subjects were healthy in each group. Most of the study subjects were 
female in the intervention group of 22 infants (73.3\%) and the control group of 20 infants (66.7\%). The status of infants of the second child in each group are 13 infants (43.3\%).

The results of the characteristics of the study subjects in mothers showed that the most maternal age was 20-35 years for the intervention group of 25 mothers (83.3\%) and the control group was 28 mothers (93.3\%). Most of the study subjects did not work (IRT) amounting to 25 mothers (83.3\%) in each group. Family income level $\geq$ minimum regional wage amount to 27 mothers (90\%) and control group of 25 (83.3\%). Mothers were mostly SHS graduate of 19 mothers (63.3\%) in the intervention group and 18 infants (60\%) in the control group.

Table 1. The Characteristics of Study Subjects

\begin{tabular}{|c|c|c|c|c|c|c|}
\hline Characteristics & Criteria & $\mathbf{n}$ & $\%$ & $\mathbf{n}$ & $\%$ & p \\
\hline \multirow{4}{*}{ Infants' Age } & 3 months & 14 & 46.7 & 18 & 60 & 0.301 \\
\hline & 4 months & 12 & 40 & 10 & $33 \cdot 3$ & \\
\hline & 5 months & 4 & $13 \cdot 3$ & 1 & $3 \cdot 3$ & \\
\hline & 6 months & o & 0 & 1 & $3 \cdot 3$ & \\
\hline \multirow[t]{2}{*}{ Status Kesehatan } & Healthy & 30 & 100 & 30 & 100 & 1 \\
\hline & Sick & 0 & 0 & $\mathrm{O}$ & 0 & \\
\hline \multirow[t]{2}{*}{ Jenis Kelamin } & Male & 8 & 26.7 & 10 & $33 \cdot 3$ & 0.120 \\
\hline & Female & 22 & $73 \cdot 3$ & 20 & 66.7 & \\
\hline \multirow[t]{4}{*}{ Status Bayi } & One & 10 & $33 \cdot 3$ & 8 & 26.7 & 0.828 \\
\hline & Two & 13 & $43 \cdot 3$ & 13 & 43.3 & \\
\hline & Three & 5 & 16.7 & 6 & 20 & \\
\hline & Others & 2 & 6.7 & 3 & 10 & \\
\hline \multirow[t]{3}{*}{ Umur Ibu } & $<20$ years & 0 & 0 & 0 & $\mathrm{O}$ & 0.651 \\
\hline & 20-35 years & 25 & $83 \cdot 3$ & 28 & 93.3 & \\
\hline & $\geq 35$ years & 5 & 16.7 & 2 & 6.7 & \\
\hline \multirow[t]{4}{*}{ Pekerjaan Ibu } & Civil & 2 & 6.7 & 3 & 10 & 1.000 \\
\hline & servant/Soldier & 3 & 10 & 1 & $3 \cdot 3$ & \\
\hline & Entrepreneur & 0 & 0 & 1 & 3.3 & \\
\hline & $\begin{array}{l}\text { Private } \\
\text { Housewife }\end{array}$ & 25 & $83 \cdot 3$ & 25 & 83.3 & \\
\hline Tingkat & $<$ Minimum & 3 & 10 & 6 & 20 & 0.647 \\
\hline Pendapatan & $\begin{array}{l}\text { wage } \\
\geq \text { Minimum } \\
\text { wage }\end{array}$ & 27 & 90 & 24 & 80 & \\
\hline \multirow[t]{5}{*}{ Pendidikan Ibu } & PS graduate & 1 & $3 \cdot 3$ & 1 & $3 \cdot 3$ & 0.436 \\
\hline & JHS graduate & 4 & $13 \cdot 3$ & 2 & 6.7 & \\
\hline & SHS graduate & 19 & 63.3 & 18 & 60 & \\
\hline & D1-D3 graduate & 4 & $13 \cdot 3$ & 7 & $23 \cdot 3$ & \\
\hline & $\mathrm{D} 4 / \mathrm{S} 1$ graduate & 2 & 6.7 & 1 & 3.3 & \\
\hline
\end{tabular}

\section{Bivariate Analysis}

The variables in this study were infant massage, sleeping quality, gross motoric, and fine motoric development. The method used is Mann Whitney. Based on the Mann Whitney Test different test on sleep quality, it showed that $\mathrm{p}<0.001$ and it means that there were significant differences between the intervention group and the control group. In gross motor development, $(\mathrm{p}=$ o.043) showed that there were significant differences between the intervention group and the control group. In fine motor development, $\mathrm{p}$ 0.018 shows that there are significant differences between the intervention group and the control group. 
Table 2. Mann Whitney test variable sleep quality, gross motor development, and fine motoric massage groups and no massage before treatment

\begin{tabular}{lccccc}
\hline \multicolumn{1}{c}{ Variable Group } & n & Mean & Median & SD & p \\
\hline Sleeping quality & & & & & \\
$-\quad$ massage & 30 & 5.63 & 5.00 & 1.71 & 0.632 \\
$-\quad$ no massage & 30 & 5.77 & 6.00 & 1.92 & \\
Gross motoric development & 30 & 2.80 & 3.00 & 0.99 & 0.975 \\
- massage & 30 & 2.77 & 3.00 & 1.17 & \\
- no massage & & & & & \\
Fine motoric development & & & & & \\
- massage & 30 & 1.57 & 2.00 & 0.68 & 0.388 \\
- no massage & 30 & 1.40 & 2.00 & 0.77 & \\
\hline
\end{tabular}

Table 3. Mann-Whitney test variable difference in sleep quality, gross motor development, and fine motor massage group and no massage

\begin{tabular}{lccccc}
\hline \multicolumn{1}{c}{ Variable Group } & n & Mean & Median & SD & p \\
\hline Sleeping quality & & & & & \\
- massage & 30 & 1.83 & 2.00 & 1.80 & $<0.001$ \\
- no massage & 30 & 0.30 & 0.00 & 0.95 & \\
Gross motoric development & 30 & 0.63 & 0.00 & 0.81 & 0.043 \\
- massage & 30 & 0.03 & 0.00 & 0.72 & \\
- no massage & & & & & \\
Fine motoric development & & & & & \\
- massage & 30 & 0.63 & 0.00 & 0.81 & 0.018 \\
- no massage & 30 & 0.20 & 0.00 & 0.48 & \\
\hline
\end{tabular}

\section{DISCUSSIONS}

1. The Effect of Baby Massage on Sleep Quality of Infants Aged 3-6 Months Old

The result of this study showed that infants who got massage were more likely to have good sleep quality than infants who did not get massage, therefore, it can be concluded that there was an effect of massage on sleep quality of infants aged 3-6 months old. In the intervention group, babies who had good sleep quality increased during the post-test than during the pre-test.

This was in accordance with a study done by Shadik (2011) which showed the result of statistical test by using Wilcoxon match pairs test which was $\mathrm{p}=0.002$, therefore, it can be concluded that there was an enhancement of sleep quality after the massage was given, from the bad sleep quality into good sleep quality. At the pre- test, 10 infants (33.3\%) had poor sleep quality and at the post-test, their sleep quality became good. During the pre-test, the infants who had good sleep quality were $20(66.7 \%)$ and during the post-test, the infants who had good sleep quality were 30 (100\%).

Infant's sleep was highly important in supporting the process of growth and development of a baby that determined the stage of subsequent baby development. When the infants were sleeping, there would be an improvement in brain cells and growth hormone production and the development would occur by $75 \%$.

Based on a study done by Guyton (2013) which observed the effect of baby massage to improve the sleep quality, in the intervention group at pre test, there were 20 infants who needed less than an hour to fall asleep after woke up, and during post 
test, there were 29 infants who needed less than an hour to be able to sleep after woke up.

According to a study done by Field (2006) it showed that baby massage could affect the occurrence of sleep hormone melatonin, so the baby's sleep patterns became regular. Infants aged 3-6 months old tend to have irregular sleep patterns. Therefore, baby massage was needed so that the infant has a more regular and quality sleep-wake pattern and better performance than babies who have irregular sleep patterns.

Baby massage could help to release oxytocin and endorphins which could overcome the discomfort. Lack of sleep in the infants could have a negative impact on the physical and cognitive development of the infants which was an indicator of health development, especially the ability to think as an adult in the future. It was recommend that the baby's sleep duration at 3-6 months old was more than the infants' condition when they woke up. The majority of infants aged 3-6 months old sleep duration was between 12-14 hours/day. In addition, the infants who got massage mostly have a fast duration to fall asleep (AMTA, 2008; Harkreader et al., 2007; Rini, 2008; Roesli, 2007).

Increased sleep duration in infants when they got massage was caused by an increase in the level of activity of neurotransmitter serotonin which produced during the massage, so that the capacity of receptor cells to bind the glucocorticoids was increased and there was a decrease in the levels of adrenaline (cortisol hormone) hormones, so that the infants felt relaxed, more comfortable and calm while sleeping (Roesli, 2009; Yahya, 2011).

A study done by Field (2006) showed a significant result. Infants who got baby massage therapy with moderate massage pressure were more likely to improve their sleep quality compared to infants who got baby massage therapy with mild massage pressure.

Another study showed that babies who have a gestation period of less than 36 weeks (birth weight less than $2500 \mathrm{~g}$ ) and got baby massage therapy until the 8 months old have good sleep quality by reducing the frequency of awakening and accelerating the duration of the baby to fall asleep after woke up (Kelmanson, 2006).

\section{The Effect of Baby Massage on \\ Gross Motor Development of Infants Aged 3-6 Months Old}

The result of this study showed that infants who got massage were more likely to have good gross motor development than infants who did not get massage. Therefore, it can be concluded that there was an effect of massage on gross motor development of infants aged 3-6 months old.

The result of this study was in accordance with a study done by Widodo and Herawati (2008) which showed that there was an effect of massage on gross motor development of infants aged 3-4 months old, with the score of $\mathrm{p}<0.001$ the infants' ability to crawl or to lift their heads and hold for more than a minute by holding their heads up by $45^{\circ}-90^{\circ}$, the ability to pull to sit or the ability of the baby from a supine sleeping position then the head was lifted to a sitting position, and the ability to roll.

The result of this study showed that infants who have gross motor development in the intervention group that was in accordance with the development during pre-test showed an increase in gross motor development in infants at the post test after they got baby massage treatment.

According to a study done by Field et al., (2006), it showed that infants who got massage with moderate pressure showed an 
increase in gross motor compared to babies who got light pressure massage. Baby massage would stimulate the baby's tactile so that their development increased rapidly and easily performed complex or coordinated movements. Squeeze movements on baby massage could strengthened the infants' muscles (Levy and Hyman, 1993; Roesli, 2013).

The vagus nervous activity caused an increase in the level of enzyme absorption in gastrin and insulin. Insulin played a role in the process of carbohydrate metabolism, glycogen storage, and synthesis of fatty acids that would be stored in the liver, fat, and muscles. One of the glycogens would produce ATP which functioned for muscle contraction. Adequate availability of ATP would make the infants to be more active in activities, so that it would accelerate motor development in infants (Pamela, 1993 in Widodo and Herawati, 2008).

The result of this study was in accordance with a study done by Utami et al., (2015) which showed that there was a relationship between baby massage and motor development of infants aged 1-12 months old.

Good stimulation can improve motor development in infants. The end and middle brain functioned as a reflex controller, level of consciousness, and vital functions of the body, such as respiration and elimination. The middle brain was surrounded by the cerebrum and cerebral cortex which controlled the voluntary movements, perception, and intellectual functions, such as learning, thinking, and communicating. The first part of the cerebrum to matur was useful for controlling the simple motor activities, such as hand and foot movements (Amstrong, 2003).

\section{The Effect of Baby Massage on Fine Motor Development of Infants Aged 3-6 Months Old}

The result of this study showed that infants who got massage were more likely to have good fine motor development than infants who did not get massage. Therefore, it can be concluded that there was an effect of massage on fine motor development of infants aged 3-6 months old. According to the results of this study, the fine motor development in the intervention group experienced an increase in the number of infants according to the development during the post test.

Motor development was the development of body movement control through the coordination of activation of the central, peripheral, and muscular nerves. Control of this movement arised from the development of reflexes that begin at birth. A study done by Schanberg in 1989 showed that touch, tactile or massage affected the production of the ODC (ornithin decarboxylase) enzyme, which was an enzyme that was sensitive to cell growth and tissue development, the release of growth and development hormones (Roesli, 2007; Sears et al., 2007).

According to a study done by Askary and Aliabadi (2011), it showed that there was an increase in motor development in the control group which was treated three times a day for 10 days with $\mathrm{p}<0.001$. Developing children's intelligence required three basic needs, namely physical, emotional, and early stimulation needs. The three basic needs must be provided simultaneously. One of the ways was to ask the children to talk and play. Asking the babies to play was also very effective to stimulate fine and gross motoric development of the neck, body, legs, hands and fingers. When playing a game, the fine motor skills would be trained by picking up toys, touching, and 
holding with five fingers (Adriana, 2013; Rodrigues et al., 2008).

This was in accordance with Piaget's theory quoted by Sulistyawati (2013), which stated that cognitive development of children aged 0-2 years was motorized sensory in which the development of the five senses was very influential for the children. Their biggest desire was the desire to touch and hold because they were driven by the desire to know the reaction of their actions. By massaging the infants, the mothers could stimulate all the five senses needed for motor sensory development and storytelling. One of the stimulations that could be done on the infants to stimulate their various developments was motor development. Stimulation given to the infants must be good in terms of both quality and quantity, and in accordance with the infant's nerve maturity level (Soetjiningsih and Ranuh, 2014).

Based on the results of the research and discussion, there were several conclusions of this study. There was an effect of baby massage on the enhancement of sleep quality in infants aged 3-6 months old. There was an effect of baby massage on the enhancement of gross motor development in infants aged 3-6 months old. There was an effect of baby massage on the enhancement of fine motor development in infants aged 3-6 months old.

\begin{tabular}{l}
\hline REFERENCES \\
\hline Adriana D (2013). Tumbuh kembang dan \\
terapi bermain pada anak. Jakarta: \\
Salemba Medika. p. 8-9. \\
American Massage Therapy Association
\end{tabular}
(AMTA) (2008). Massage therapy may benefit newborns. Accessed October 2016.

Amstrong T (2003). Smart baby's brain. Prestasi Pustakaraya: Jakarta.
Askary RK, Aliabadi F (2013). Effect of Tactile-Kinesthetic Stimulation on Motor Development of Low Birth Weight Neonates. Iranian Journal of Pediatrics. 23(3): 289-294.

Chamidah AN (2009). Deteksi Dini Gangguan Pertumbuhan dan Perkembangan Anak. Jurnal Pendidikan Khusus. 5(2): 83-93.

Champion for Children's Health (2016). Fine Motor Skills: Birth to 2 years. Accessed October, 2016.

Field T, Diego MA, Hernandez-Reif M, Deeds O, Figuereido B (2006). Moderate Versus Light Pressure Massage Therapy Leads to Greater Weight Gain in Preterm Infants. Infant Behav Dev. 29(4): 574- 578. Doi: 10.1016/j.infbeh.2006.07.011.

Gabbard C, Rodrigues L (2008). Optimizing Early Brain And Motor Development Through Movement. Early Childhood News. Accessed October 2016.

Guyton H (2007). Buku ajar fisiologi kedokteran. Edisi Sebelas. Jakarta: EGC.

Harkreader H (2007). Fundamental of nursing (3rd ed.) . St. Louis Saunders: Courtesy Ballard Medical Products Draper UT.

Halimah A, Suharto, Fajriah SN (2012). Pengaruh Stimulasi Bayi terhadap Perkembangan Motorik Kasar pada Bayi Usia 3-8 Bulan. Jurnal Ilmiah. 5(1).

Helen S, Lydia L, Karen M (2005). The Benefit of Baby Massage. Pediatric Nursing Journal. 17(2).

Aliabadi F, Askary RK (2011). Effect of Tactile-Kinesthetic Stimulation on Motor Development of Low Birth Weight Neonates. Iranian Rehabilitation Journal. 9 (13): 16-18. 
Kelmanson IA, Adulas EI (2006). Massage Therapy and Sleep Behaviour in Infant Born with Low Birth Weight. Complement Ther Clin Pract. 12(3): 200-205. Doi: 10.1016/j.ctcp.2005.11.007.

Kementerian Kesehatan Republik Indonesia (2009). Pedoman Pelaksanaan Stimulasi, Deteksi Dan Intervensi Dini Tumbuh Kembang Anak di Tingkat Pelayanan Kesehatan Dasar. Jakarta: Kementerian Kesehatan Republik Indonesia.

(2010). Instrument Stimulasi, Deteksi, dan Intervensi Dini Tumbuh Kembang Anak. Jakarta: Kementerian Kesehatan Republik Indonesia.

Keputusan Menteri Kesehatan Republik Indonesia (2007). Standar Profesi Bidan. Jakarta: Kepmenkes RI.

Levy SE, Hyman SL (1993). Pediatric Assessment of The Child with Developmental Delay. Pediatric Clin North Am. NCBI. 4O(3): 465-477.

Pamela ME (1993). Elements of Pediatric Physiotherapy, Churchill Livingstone.

Prasetyono DS (2013). Buku Pintar Pijat Bayi. Yogyakarta: Buku Biru.

Rini (2008). Panduan praktis Memijat Buah Hati Anda. Yogyakarta: Nusa Pressindo.

Roesli U (2007). Pedoman pijat bayi. Jakarta: PT. Trubus Agriwidya. (2008). Pedoman Pijat Bayi. Edisi Revisi. Jakarta: PT Trubus Agriwidia. (2009). Pedoman Pijat Bayi. Jakarta: Trubus Agriwidya. (2013). Pedoman Pijat Bayi. Jakarta: Pustaka Pembangunan Swadaya Nusantara.

Ruffin PT (2011). A History of Massage in Nurse Training School Curricula (1860-1945). Journal Holistic Nurse. 29 (1): 61-67.
Schoefer Y, Zutavern, Brockow I, Schafer T, Kramer U, Schaaf B, Herbarth O, von Berg A, Wichmann HE, Heinrich J (2007). Health Risks of Early Swimming Pool Attendance. Int Journal Hyg Environment Health. 211(3-4): 367-73. Doi: 10.1016/j.ijheh.2007.08.001

Shadik N (2011). Pengaruh Pijat Bayi Terhadap Kualitas Tidur Bayi Usia 6-12 Bulan di Rumah Bersalin Rachmi Yogyakarta Tahun 2011. Yogyakarta: STIKES Aisyah.

Sears W, Martha S, Robert S, James S (2008). The Baby Book. Jakarta: Serambi Ilmu Semesta.

(2013). The Baby Book: Everything You Need to Know about Your Baby From Birth to Age Two. Jakarta: Serambi Ilmu Semesta.

Soetjiningsih, Gde Ranuh IGN (2014). Tumbuh Kembang Anak. Edisi II. Jakarta : EGC. p. 2-109.

Sulistyawati A (2013). Deteksi Tumbuh Kembang Anak. Jakarta: Salemba Medika.

Underdown A, Barlow J, Brown SS (2010). Tactile Stimulation in Phsysically Health Infants: Result of a Systematic Review. Journal of Reproductive and Infant Psycology. 28 (1): 11-29. https://doi.org/10.1080/02646830903247209.

Utami A, Setyaningsih R, Wati KEP (2015). Hubungan Pijat Bayi Dengan Perkembangan Motorik Bayi Usia 1-12 Bulan di Desa Pundungsari Bulu Sukoharjo. JIK. 3(1): $50-58$.

Widiyanti M (2008). Hubungan Pijat Bayi dengan Pola Tidur Bayi Usia 3-6 Bulan Di Bidan Praktek Swasta Ny. Numusriah Kota Kediri. Jurnal Kesehatan. 6 (2): 79-83.

Widodo A, Herawati I (2008). Efektifitas Massage Efflurage terhadap Per- 
Kusumastuti et al./ Effect of Massage on Sleep Quality and Motor Development

kembangan Gross Motoric pada Bayi Usia 3-4 Bulan. Jurnal Kesehatan. ISSN 1979-7621. 1(1): 67-72.

Yahya N (2011). SPA Bayi Dan Anak. Solo:

Metagraf.
Zero To Three (2012). Behaviour and Development. Washington DC: National Center for Infant, Toddlers and Families. 